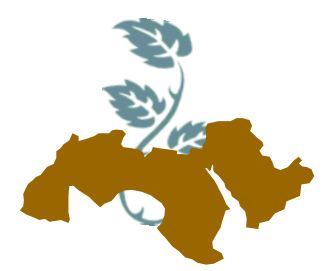

Arab Univ.

J. Agric. Sci., Ain Shams Univ., Cairo Special Issue, 26(2A), 1203-1211, 2018

\title{
IDENTIFICATION AND CHARACTERIZATION OF HEAT SHOCK PROTEINS IN FOUR EGYPTIAN MAIZE INBRED LINES (Zea mays L.)
}

\author{
Fatma E. Mahmoud ${ }^{2}$; M.A. Rashed ${ }^{1}$; K.M. Khalil ${ }^{2}$ and M.H. Abou-Deif ${ }^{2}$
}

1- Genetic Dept., Fac. of Agric., Ain Shams Univ., Cairo, Egypt

2- Genetic and Cytology Dept., National Research Centre, Dokki, Giza, Egypt

Keywords: Maize, Heat shock, proteins, Electrophoresis

\section{ABSTRACT}

The heat shock protein (HSP) family is one of the proteins universally accumulated under heat stress condition. Four Egyptian maize inbred lines (Zea mays L.) were studied to identify heat shock proteins under heat stress at $45^{\circ} \mathrm{C}$ as protein markers for detecting the thermo-tolerance inbreds. The protein fingerprints of four inbred lines were performed by grain total-soluble protein electcophoretic analysis. The protein electrophoretic analysis showed 18 bands in a distinct pattern of $\mathrm{K} 1$ and $\mathrm{K} 7$ inbred lines, while 17 bands were present in G342 and Rg59 inbred lines as another distinct pattern indicating different genotypes. The high temperature effect on four maize inbred lines exposed to $45^{\circ} \mathrm{C}$ for 2 and 4 hours at 14-days old seedlings besides control $\left(25^{\circ} \mathrm{C}\right)$ was studied. Several protein bands varied between low and intermediate molecular weights were induced after exposing to heat stress at $45^{\circ} \mathrm{C}$. Four bands of heat shock proteins with molecular weights of 82 , 22, 17 and $10 \mathrm{kDa}$ appeared in the inbred line $\mathrm{K} 1$ after exposing to $45^{\circ} \mathrm{C}$ for 2 and 4 hours which may be indication of thermo-tolerance. Four and seven bands were enhanced after exposing to high temperature for 4 hours at $45^{\circ} \mathrm{C}$ which appeared more concentrated in the patterns of $\mathrm{K} 7$ and $\mathrm{G} 342$ inbred lines, respectively.

\section{INTRODUCTION}

Sodium dodecyl sulfate polyacrylamide gel electrophoresis (SDS-PAGE) is useful for characterizing, comparing and differentiating corn endosperm proteins in protein isolation studies and ge- netic investigation (Paulis et al 1975). Ladizinsky and Hymowitz (1979) found that the high stability of the seed protein profile and its additive nature make seed protein electrophoresis a powerful tool in elucidating the origin and the evolution of cultivated plants. Chun et al (2001).

Reported that PAGE technology can be used to determine the purity of inbred lines and can provide the basis for controlling fake seeds. Gorinstein et al (2004) screened soybean and maize for proteins and their nutritional value. The comparison of the identity and differences between investigated plants was carried out by the obtained SDS-PAGE electrophoretic patterns. Electrophoretic patterns of extracted proteins have shown that the main protein subunits were concentrated between 10 and $50 \mathrm{kDa}$. Variations were found in major fractions and minor bands as well as in the fine structure. Zeb et al (2006) showed that the SDS-PAGE electrophoretic analysis, together with physiochemical and molecular characteristics, present a good tool to characterize seed storage protein.

Shende (2017) characterized 170 genotypes of rice (Oryza sativa L.), based on the total seed protein and analyzed through protein Bradford assay and biochemical characters (sodium dodecyl sulfate polyacrylamide gel electrophoresis, SDSPAGE). The study revealed that the all genotypes of rice were identified on the basis of total seed protein content. Total of 15 protein bands was observed in SDS-PAGE, eight polymorphic bands were scored.

Cooper and Ho (1983) showed that the pattern of protein synthesis in maize seedlings (Zea mays L.) is rapidly altered when the incubation temperature is raised from 25 to $40^{\circ} \mathrm{C}$. Shifting the temperature from 25 to $45^{\circ} \mathrm{C}$ results in a pattern of protein synthesis different from that observed after a shift 
to $40^{\circ} \mathrm{C}$. Normal protein synthesis continues, which are produced in small amounts at lower temperatures, show greatly enhanced synthesis at $45^{\circ} \mathrm{C}$. These proteins have apparent molecular weights of $83,81,68$, and $65 \mathrm{kDa}$. Schlesinger (1990) reported that the heat shock protein (HSP) super family is one of the proteins universally accumulated under heat stress condition. Vierling (1991) found that SHSPs are divided into six classes based on their sequence alignments, immunological cross reactivity, and cellular compartmentalization. Three classes (I, II, and III) are localized in the cytoplasm or the nucleus and the other three are localized in the chloroplast, the endoplasmic reticulum, and the mitochondria.

Hogan (1990) found that maize plumules responded to heat shock by synthesizing nuclearencoded HSPs with MW of 108, 89, 84, 76, 73 and $17-29 \mathrm{kDa}$ and at $25^{\circ} \mathrm{C}$ (control) some proteins were repressed in vivo. Ristic et al (1991) using one-dimensional (1-D) SDS PAGE, found a band of HSP of $45 \mathrm{kDa}$ in the leaves of 3-week-old plants of a drought and heat resistance maize (Zea mays L.) line, ZPBL1304. A similar HSP band of $45 \mathrm{kDa}$ was lacking in the leaves of a drought and heat sensitive maize line. Gallagher et al (1993) performed separation of proteins by SDS-PAGE on $10 \%$ polyacrylamide gels for the detection of HSP101 and HSP70 and on $15 \%$ polyacrylamide gels to detect HSP 17.8 and HSP 17.6. Waters et al (1996) reported that plants which exposed to temperature of $8^{\circ} \mathrm{C}$ to $10^{\circ} \mathrm{C}$ above their normal growth temperature (heat stress) synthesize a set of new proteins, called the heat shock proteins (HSPs), they are play a role in protection against heat injury. Also observed that all small-HSPs in plants are encoded by six nuclear gene families, each gene family corresponding to proteins found in distinct cellular compartments like cytosol, chloroplast, endoplasmic reticulum $(E R)$, mitochondria and membranes. Some nuclear-encoded HSPs accumulate in the cytosol at low $\left(27^{\circ} \mathrm{C}\right)$ and high $\left(43^{\circ} \mathrm{C}\right)$ temperatures, but they accumulate in chloroplast at moderate $\left(37^{\circ} \mathrm{C}\right)$ temperatures.

Giaveno and Ferrero (2003) reported, in temperate regions, that heat stress is one of the most important causes of reduction in yield and dry matter production in many crops, including maize. Also found that some temperate areas of the world behave as sub-tropical due to greenhouse effect and global warming. Therefore, more temperate genotypes show a decrease in yield and dry matter production as consequence of heat stress. Baniwal et al (2004) found that high temperature is one of the major limiting factors that could considerably reduce the yield of crops and impair their wider distribution. Therefore, exploring the complex molecular mechanism of plant response to HS has become a crucial subject of agricultural significance in recent years. Heat shock transcription factors (Hsfs) are the critical components that serve to regulate the expression of genes responsive to HS as transcription factors.

Sanmiya et al (2004) placed the plant HSPs by molecular weight into six groups: HSP100s; HSP90s; HSP70s; HSP60s; and small HSPs (sHSPs) (12-40 kDa) and co-chaperones HSP40 or DNAJ family. Wahid and Close (2007) manifested that expression of stress proteins is an important adaptation to crop with environmental stresses. Most of the stress proteins are soluble in water and therefore contribute to stress tolerance presumably via hydration of cellular structures, although heat shock proteins (HSPs) are exclusively implicated in heat-stress response, certain other proteins are also involved. Timperio et al (2008) reported that plants respond to various stresses in a similar manner by producing heat shock proteins (HSPs), indicating a similarity in the plant's adaptive mechanisms; in which HSPs protect cells against many stresses. Muthusamy et al (2017) observed that small Heat Shock Proteins (sHSPs)/HSP20 are molecular chaperones that protect plants by preventing protein aggregation during abiotic stress conditions, especially heat stress. Due to global climate change, high temperature is emerging as a major threat to wheat productivity. Thus, the identification of HSP2O and analysis of HSP transcriptional regulation under different abiotic stresses in wheat would help in understanding the role of these proteins in abiotic stress tolerance.

The objectives of this study are analysis and fingerprinting of four Egyptian maize inbred lines by total protein electrophoretic analysis of maize embryos and characterization of heat shockinduced proteins for using as molecular markers to improve the heat stress tolerance in Egyptian maize inbred lines.

\section{MATERIALS AND METHODS}

\section{MATERIALS}

Four Egyptian inbred lines of maize (Zea mays L.) with different genetic background, as shown in Table (1), were used in this study. Two inbred lines $\mathrm{K} 1$ and line $\mathrm{K} 7$ were developed by the plant breed- 

maize inbred lines (Zea mays L.)

ing group, Genetics and Cytology Dept., National Research Centre, Giza, Egypt. While line K1 was derived after selfing for several years to single cross 10 (introduced from the Maize Research Section, Agriculture Research Center, Ministry of Agriculture, Giza, Egypt. In addition, the other two inbred lines G342 and line Rg59 were kindly obtained by the Maize Research Section, Agriculture Research Center, Ministry of Agriculture, Giza, Egypt.

Table 1. The four maize inbred lines used in the study and their pedigrees

\begin{tabular}{|l|l|l|}
\hline No. & $\begin{array}{l}\text { Maize } \\
\text { lines }\end{array}$ & Pedigree \\
\hline 1 & K1 & Single Cross 10 (S.C.10) \\
2 & K7 & 2-synthetic variety \\
3 & G342 & LocBrod SC12100 \\
4 & Rg59 & G.S. (Syn.Laposta X 307) X S.C.14 \\
\hline
\end{tabular}

\section{METHODS}

Plant materials and seed storage proteins extraction for fingerprinting

Total soluble proteins were extracted from embryos the four maize inbred lines by salt-buffer as follow;

$50 \mathrm{mM}$ Tris- $\mathrm{HCl}$ buffer $\mathrm{pH} 8$

$200 \mathrm{mM} \mathrm{NaCl}$

$1 \%$ SDS

$2 \% \beta$-mercaptoethanol

Protease inhibitors (1 mM PMSF, $50 \mu \mathrm{M}$ Leupeptin and $10 \mathrm{mM} \mathrm{E-64).}$

Centrifugation for $10 \mathrm{~min}$ at $12,000 \mathrm{rpm}$ and $4^{\circ} \mathrm{C}$ was carried out and the supernatants containing total soluble proteins were transferred to new eppendorf tubes and kept at deep-freeze until using for electrophoretic analysis. Electrophoresis was carried out and then the gel was stained with Coomassie Brilliant Blue R 250. The de-staining solution containing $300 \mathrm{ml}$ methanol, $50 \mathrm{ml}$ acetic acid and $650 \mathrm{ml}$ distilled water was used to clear the protein bands. They were photographed and scanned by Gel Doc Bio-Rad System (Gel - Pro analyzer V. 3).
Protein extraction from leaves 14 day-old maize seedlings was also performed under similar conditions. Protein extracts were quantified using the Bradford reagent and analyzed by SDS-PAGE (13\% polyacrylamide). Extracted proteins were analyzed by one-dimensional sodium dodecyl sulfate polyacrylamide gel electrophoresis (SDSPAGE) which was performed on vertical slabs (20 $X 18 \times 0.2 \mathrm{~cm}$ ) according to Laemmli (1970).

\section{Heat stress condition assay by 1D-SDS PAGE}

The heat shock proteins were analyzed for the four lines of maize. One gram of leaves of 14 dayold maize seedlings, exposed to heat shock $\left(45^{\circ} \mathrm{C}\right)$ for 2 and 4 hours besides control $\left(25^{\circ} \mathrm{C}\right)$, were finely ground in a mortar and pestle. $0.2 \mathrm{~g}$ ground sample was first added to $1 \mathrm{ml}$ extraction buffer in an eppendorf tube and left in refrigerator overnight, then vortexed for 15 seconds and centrifuged at $12,000 \mathrm{rpm}$ and $4^{\circ} \mathrm{C}$ for $15 \mathrm{~min}$. The electrophoretic procedure was performed as mentioned above. The protein extraction was maintained at $-20^{\circ} \mathrm{C}$ until further use.

\section{RESULTES AND DISCUSSION}

\section{Protein purification and electrophoresis}

The embryo total protein electrophoretic patterns for the four maize inbred lines are shown in Figure (1) and Table (2). The electrophoretic patterns showed 18 protein bands in both of $\mathrm{K} 1$ and K7 inbred lines in the same loci but different in density and intensity, while the other two lines G342 and Rg59 manifested 17 bands equal in the molecular weights with different density and intensity. The protein band patterns are ranging in molecular weights from 10 to $170 \mathrm{kDa}$.

The results are in accordance with those of Gepts (1989) who reported that, among biochemical techniques, SDS-PAGE is most widely used due to its validity and simplicity for genetic structure of crop germplasm. The SDS-PAGE is a practical reliable method because a seed storage protein is largely independent of environmental fluctuation. Bean and Lookhart (2000) showed that SDS-PAGE method has been developed to separating and characterizing cereal storage proteins. Gorinstein et al (2004) screened soybean and maize for proteins by SDS-PAGE electrophoretic patterns which found that the main protein subunits were concentrated between 10 and $50 \mathrm{kDa}$. 


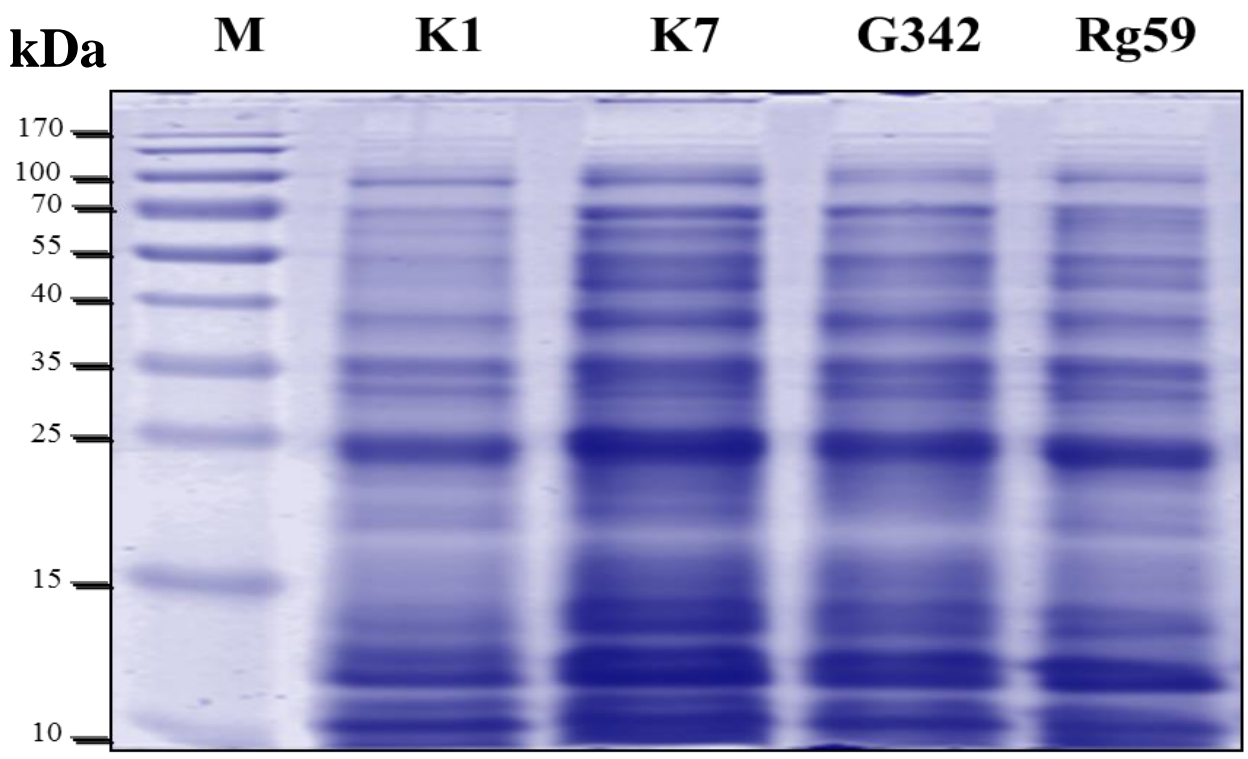

Fig. 1. Profile of total proteins of maize embryos performed by SDS-PAGE analysis for the four inbred lines as indicated at the top of the figure. M: molecular weight in kD of standard proteins

Table 2. SDS-PAGE profile of embryos total proteins of four maize inbred lines, representing band number and molecular weight (MW), where $(+)$ means presence and $(-)$ means absence of band.

\begin{tabular}{|c|c|c|c|c|c|}
\hline \multirow{2}{*}{ Band No. } & \multirow{2}{*}{ MW (kDa) } & \multicolumn{4}{|c|}{ Maize inbred lines } \\
\hline & & K1 & K7 & G342 & Rg59 \\
\hline 1 & 168.2 & + & + & + & + \\
\hline 2 & 158.7 & + & + & + & + \\
\hline 3 & 102.1 & + & + & + & + \\
\hline 4 & 95.6 & + & + & + & + \\
\hline 5 & 70.2 & + & + & + & + \\
\hline 6 & 64.1 & + & + & + & + \\
\hline 7 & 55.2 & + & + & + & + \\
\hline 8 & 49.4 & + & + & + & + \\
\hline 9 & 38.4 & + & + & + & + \\
\hline 10 & 35.0 & + & + & + & + \\
\hline 11 & 30.5 & + & + & + & + \\
\hline 12 & 24.8 & + & + & + & + \\
\hline 13 & 22.0 & + & + & - & - \\
\hline 14 & 20.1 & + & + & + & + \\
\hline 15 & 18.0 & + & + & + & + \\
\hline 16 & 14.3 & + & + & + & + \\
\hline 17 & 13.3 & + & + & + & + \\
\hline 18 & 11.2 & + & + & + & + \\
\hline \multicolumn{2}{|c|}{ Total bands } & 18 & 18 & 17 & 17 \\
\hline
\end{tabular}

\section{Effect of high temperature on protein synthesis}

Figure (2) and Table (3) illustrate the effect of heat stress on heat shock protein (HSP) synthesis in two maize inbred lines ( $\mathrm{K} 1$ and $\mathrm{K} 7$ ) exposed to $25^{\circ} \mathrm{C}$ and $45^{\circ} \mathrm{C}$ for two and four hours. The elec- trophoretic patterns for protein bands gave a total of 16 bands ranged from 200 to $10 \mathrm{kDa}$. The exposure to heat stress induced the synthesis of several proteins varied between low and high molecular weights where some bands enhanced by heat treatments and detected only at high temperature. 

maize inbred lines (Zea mays L.)

In inbred line k1 some hsp bands were not detectable in the control but appeared after exposing to temperature at $45^{\circ} \mathrm{C}$ for 2 hours (treatment $\mathrm{T} 1$ ) such as bands of $82 \mathrm{kD}$ and $17 \mathrm{kDa}$, while after exposing to temperature at $45^{\circ} \mathrm{C}$ for 4 hours (treatment T2) two another band appeared with 22 and $10 \mathrm{kDa}$. This finding indicates that this inbred line may be having ability to tolerate high temperature stress. In addition, four bands with molecular weights $38,37,31$ and $25 \mathrm{kDa}$ in inbred line $\mathrm{k} 7$ and one band with $20 \mathrm{kDa}$ in inbred line $\mathrm{K} 1$, increased in protein concentration after heat treatment at $45^{\circ} \mathrm{C}$ for 4 hours. Also, four bands with molecular weights of 200, 38, 37 and $25 \mathrm{kDa}$ appeared more concentrated after exposing to $45^{\circ} \mathrm{C}$ for 2 hours more than $25^{\circ} \mathrm{C}$ in inbred line K1.

Figure (3) and Table (4) illustrate the effect of heat stress on heat shock protein (HSP) synthesis in the two maize inbred lines G342 and Rg59 exposed to $25^{\circ} \mathrm{C}$ and $45^{\circ} \mathrm{C}$ for two and four hours. The SDS-PAGE revealed a total of 16 bands ranged from 200 to $10 \mathrm{kDa}$. In inbred line G342, some heat shock protein bands were observed in both control and heat stress at $45^{\circ} \mathrm{C}$ for 2 hours, but appeared more concentrated after heat stress more than the control. New HSP bands with $22 \mathrm{kD}$ was detected after heat stress of $45^{\circ} \mathrm{C}$ for two and four hours and $18 \mathrm{kD}$ after treatment by $45^{\circ} \mathrm{C}$ for four hours appeared in the inbred line G342. The bands which observed more detection during treatment $2\left(45^{\circ} \mathrm{C}\right.$ for 4 hours $)$ with molecular weights $106,70,55,31,22,15$ and $10 \mathrm{kDa}$. On the other hand, the inbred line Rg59 did not show differences between the electrophoretic bands in the two patterns of control and heat treatments except one band of $22 \mathrm{kD}$ was enhanced after heat stress at $45^{\circ} \mathrm{C}$ for two and four hours as HSP.

These results are in accordance with those of other researchers in their studies on HSPs, which Lindquist (1986) and Vierling (1991) found that HSPs ranging in molecular mass from 10 to 200 $\mathrm{kDa}$ and are involved in signal transduction during heat stress and protect of functional sites from the adverse effects of high temperature. Morimoto and Santoro (1998) indicated that Hsps protect cells from injury and facilitate recovery and survival after a return to normal growth conditions. Sun et al (2002) revealed that SHSPs cannot refold nonnative proteins, but they can bind to partially folded or denatured substrates proteins, preventing irreversible unfolding or wrong protein aggregation Nakamoto and Vigh (2007) concluded that there were some indications that small heat shock proteins play an important role in membrane quality control and thereby potentially contribute to the maintenance of membrane integrity especially under stress conditions.

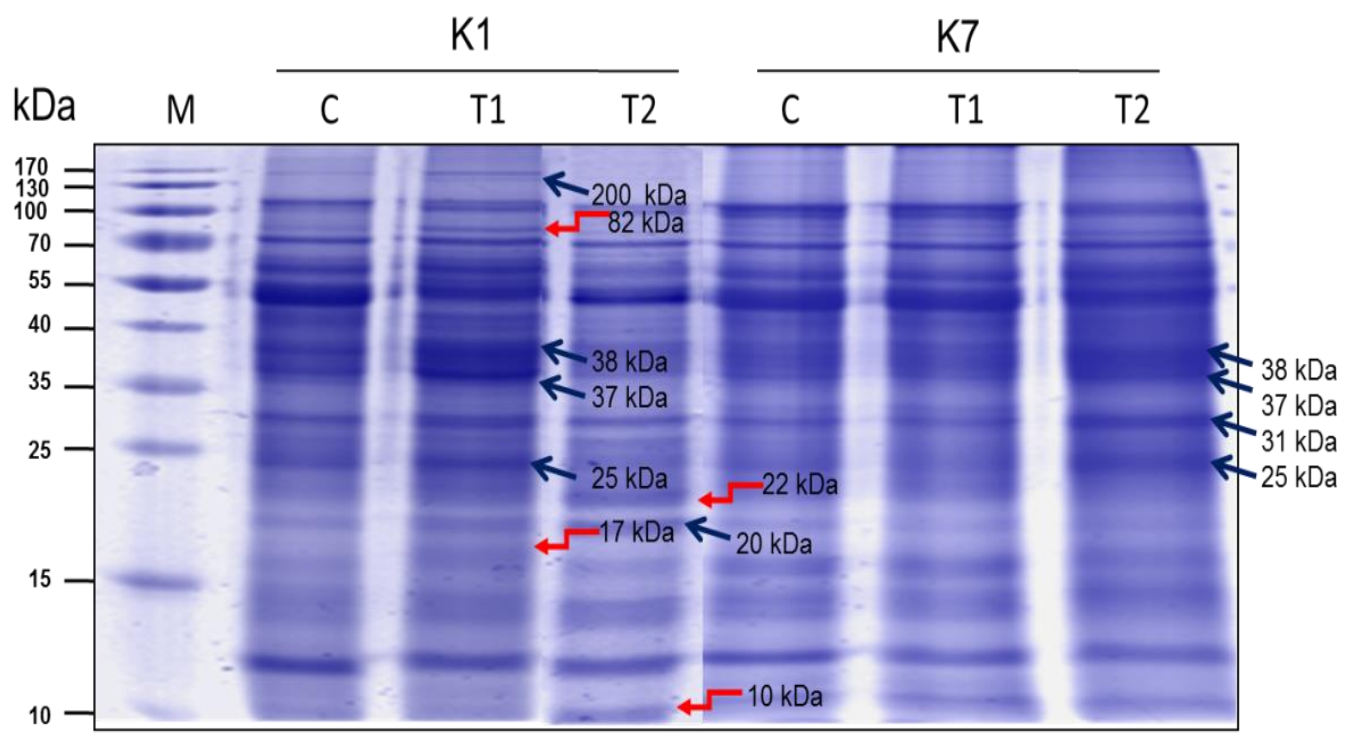

Fig. 2. Coomasie Brillient Blue-stained SDS-PAGE of total leaf proteins ( $25 \mu \mathrm{g} / \mathrm{lane}$ ) extracted from control and heat treated plants of indicated inbred lines. $\mathrm{C}$ (control): $25^{\circ} \mathrm{C}, \mathrm{T} 1: 45^{\circ} \mathrm{C}$ for 2 hours and $\mathrm{T} 2: 45^{\circ} \mathrm{C}$ for 4 hours. M: Molecular weight in kD standard proteins. Black arrows indicate bands enhanced in heat treatments. Red arrows indicate bands only present in heat-treated extracts. 


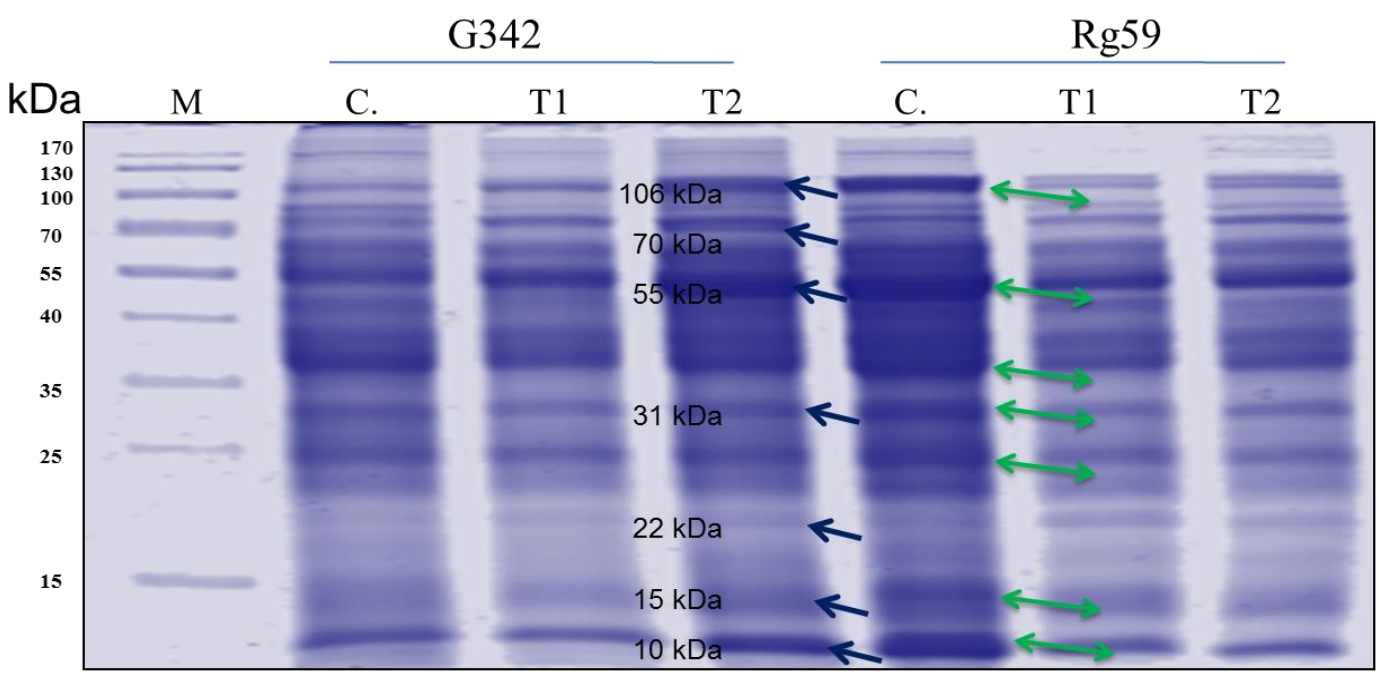

Fig. 3. Coomasie Brillient Blue-stained SDS-PAGE of total leaf proteins ( $25 \mu \mathrm{g} / \mathrm{lane})$ extracted from control and heat treated plants of indicated inbred lines. $\mathrm{C}$ (control): $25^{\circ} \mathrm{C}, \mathrm{T} 1: 45^{\circ} \mathrm{C}$ for 2 hours and $\mathrm{T} 2: 45^{\circ} \mathrm{C}$ for 4 hours. M: Molecular weight in kD standard proteins. Black arrows indicate bands enhanced in heat treatments. Green arrows indicate bands present in control but not induced by heat-treatment.

Table 3. SDS-PAGE profile for two maize inbred lines after exposing to heat shock. $\mathrm{C}$ (control): $25^{\circ} \mathrm{C}, \mathrm{T} 1$ (treatment 1): $45^{\circ} \mathrm{C}$ for 2 hours and T2 (treatment 2): $45^{\circ} \mathrm{C}$ for 4 hours. (+) means presence and (-) means absence of band

\begin{tabular}{|c|c|c|c|c|c|c|c|}
\hline \multirow{2}{*}{$\begin{array}{c}\text { Band } \\
\text { No. }\end{array}$} & \multirow{2}{*}{ M W (kDa) } & \multicolumn{7}{|c|}{ Maize inbred lines } \\
\cline { 3 - 8 } & & \multicolumn{7}{|c|}{ K1 } & T & \multicolumn{3}{c|}{ K7 } & \\
\cline { 2 - 8 } 1 & 200 & + & ++ & + & + & + & + \\
2 & 106 & + & + & + & + & + & + \\
3 & 82 & - & + & - & - & - & - \\
4 & 70 & + & + & + & + & + & + \\
5 & 63 & + & + & + & + & + & + \\
6 & 55 & + & + & + & + & + & + \\
7 & 47 & + & + & + & + & + & + \\
8 & 38 & + & ++ & + & + & + & ++ \\
9 & 37 & + & ++ & + & + & + & ++ \\
10 & 31 & + & + & + & + & + & ++ \\
11 & 25 & + & ++ & + & + & + & ++ \\
12 & 22 & - & - & + & - & - & - \\
13 & 20 & + & + & ++ & + & + & + \\
14 & 18 & + & + & + & + & + & + \\
15 & 17 & - & + & - & - & - & - \\
16 & 15 & + & + & + & + & + & + \\
17 & 13 & + & + & + & + & + & + \\
18 & 10 & - & - & + & + & + & + \\
\hline \multicolumn{2}{l}{ Total bands } & $\mathbf{1 4}$ & $\mathbf{1 6}$ & $\mathbf{1 6}$ & $\mathbf{1 5}$ & $\mathbf{1 5}$ & $\mathbf{1 5}$ \\
\hline
\end{tabular}



maize inbred lines (Zea mays L.)

Table 4. SDS-PAGE profile for two maize inbred lines after exposing to heat shock. $\mathrm{C}$ (control): $25^{\circ} \mathrm{C}, \mathrm{T} 1$ (treatment 1 ): $45^{\circ} \mathrm{C}$ for 2 hours and T2 (treatment 2): $45^{\circ} \mathrm{C}$ for 4 hours. (+) means presence and (-) means absence of band

\begin{tabular}{|c|c|c|c|c|c|c|c|}
\hline \multirow{2}{*}{ Band No. } & \multirow{2}{*}{ M W (kDa) } & \multicolumn{7}{|c|}{ Maize inbred lines } \\
\cline { 3 - 8 } & & \multicolumn{7}{|c|}{ G342 } & \multicolumn{3}{c|}{ Rg59 } \\
\cline { 2 - 8 } & 200 & $\mathbf{C}$ & T1 & T2 & $\mathbf{C}$ & T1 & T2 \\
\hline 1 & 106 & + & + & + & + & + & + \\
2 & 82 & + & + & ++ & + & + & + \\
3 & 70 & + & + & + & + & + & + \\
4 & 63 & + & + & + & + & + & + \\
5 & 55 & + & + & ++ & + & + & + \\
6 & 47 & + & + & + & + & + & + \\
7 & 38 & + & + & + & + & + & + \\
8 & 37 & + & + & + & + & + & + \\
9 & 31 & + & + & ++ & + & + & + \\
10 & 25 & + & + & + & + & + & + \\
11 & 23 & + & + & + & + & + & + \\
12 & 22 & - & + & ++ & - & + & + \\
13 & 18 & - & - & + & + & + & + \\
14 & 15 & + & + & ++ & + & + & + \\
15 & 10 & + & + & ++ & + & + & + \\
16 & & $\mathbf{1 4}$ & $\mathbf{1 5}$ & $\mathbf{1 6}$ & $\mathbf{1 5}$ & $\mathbf{1 6}$ & $\mathbf{1 6}$ \\
\hline
\end{tabular}

\section{REFERENCES}

Baniwal, S.K., Bharti, K., Chan, K.Y., Fauth, M. and Ganguli, A. 2004. Heat stress response in plants, a complex game with chaperones and more than twenty heat stress transcription factors. J. of Biosciences 29, 471-487.

Bean, S.R. and Lookhart, G.L. 2000. Electrophoresis of cereal storage proteins. J. Chromatography $881,23-36$.

Chun, F., Zhang, X., Feng, D., Junping, L. and Bingchang, Z. 2001. The identification of corn seed purity by using PAGE patterns of saltsoluble protein. Jilin Agricultura 23, 6-10.

Cooper, P. and Ho, T.D. 1983. Heat shock proteins in maize. Plant Physiol. 71, 215-222.

Gallagher, S., Winston, S.E., Fuller, S.A. and Hurrell, J.G.R. 1993. Immunoblotting and immunodetection. In Current protocols in molecular biology, eds. by Ausubel, F.M., Brent, R., Kingston, R.E., Moore, D.D., Smith, J.A., Seidman, J.G. and Struhl, K., New York: Greene Publishing and Wiley-Interscience. pp. 10.8. 1-10.8.17.

Gepts, P. 1989. Genetic diversity of seed storage proteins in plants. Plant Population Genetics, Breeding and Genetic Resources 14, 64-82.
Giaveno, C. and Ferrero, J. 2003. Introduction of tropical maize genotypes to increase silage production in the central area of Santa Fe, Argentina. Crop Breeding and Applied Biotechnology 3, 89-94.

Gorinstein, S., Pawelzik, E., Delgado, L.E., Yamamoto, K., Kobayashi, S. and Park, R. 2004. Use of scanning electron microscopy to indicate the similarities and differences in pseudo cereal and cereal proteins. J. Food Science and Technology 39, 183-189.

Hogan, N.C. 1990. Translational control of protein synthesis in heat-shocked maize seedlings. Sciences and Engineering 50, 10-16.

Ladizinsky, G. and Hymowitz, T. 1979. Seed protein electrophoresis in taxonomic and evolutionary studies. Theor. Appl. Genet. 54, 145151.

Laemmli, U.K. 1970. Cleavage of structural proteins during the assembly of head of bacteriophage T4. Nature 227, 680-685.

Lindquist, S. 1986. The heat-shock response. Annu. Rev. Biochem. 55, 1151-1191.

Morimoto, R.I. and Santoro, M.G. 1998. Stressinducible responses and heat shock proteins: new pharmacologic targets for cytoprotection. Nat. Biotechnol., 16, 833-838. 
Muthusamy, S.K., Dalal, M., Chinnusamy, V. and Bansal, K.C. 2017. Genome wide identification and analysis of biotic and abiotic stress regulation of small heat shock protein (HSP20) family genes in bread wheat. J. of Plant Physiology 211, 100-113.

Nakamoto, H. and Vigh, L. 2007. The small heat shock proteins and their clients. Cell Mol. Life Sci. 64, 294-306.

Paulis, J.W., Bietz, J.A. and Wall, J.S. 1975. Corn protein subunits: molecular weights determined by sodium dodecyl-sulphate polyacrylamid gel electrophoresis. J. Agric. and Food Chem. 23, 197-201.

Ristic, Z., Giffbrd, D.J. and Cass, D.D. 1991. Heat shock proteins in two lines of Zea mays $L$. that differ in drought and heat resistance. Plant Physiology 97, 1430-1434.

Sanmiya, K., Suzuki, K., Egawa, Y. and Shono, M. 2004. Mitochondrial small heat-shock protein enhances thermotolerance in tobacco plants. FEBS Lett. 557, 265-268.

Schlesinger, M.J. 1990. Heat shock proteins. J. Biol Chem 265, 12111-12114.

Shende, R.T. 2017. Seed storage protein profiling of rice (oryza sativa I.) genotypes using sds page (Doctoral dissertation, Indira Gandhi Krishi Vishwavidhyalaya, Raipur).

Sun, F., Robert, M. and Michael, J.S. 2002. Empty pericarp 2 encodes a negative regulator of the heat shock response and is required for maize embryogenesis. Plant Cell 14, 31193132.

Timperio, A.M., Egidi, M.G. and Zolla, L. 2008. Proteomics applied on plant abiotic stresses: role of heat shock proteins (HSP). J. Proteomics 71, 391-411.

Vierling, E. 1991. The role of heat shock proteins in plants. Plant Mol. Biol. 42, 579-620.

Wahid, A. and Close, T.J. 2007. Expression of dehydrins under heat stress and their relationship with water relations of sugarcane leaves. Biol. Plant 51, 104-109.

Waters, E.R., Lee, G.J. and Vierling, E. 1996. Evolution, structure and function of the small heat shock proteins in plants. J. Exp. Bot. 47, 325-338.

Zeb, A., Zahir, A., Ahmed, T. and Abdumanon, A. 2006. Physiochemical characteristics of wheat varieties growing in the same and different ecological regions of Pakistan, Pak. J. Bio. Sci., 9, 1823-1828. 